\title{
The New Development of the Democratic Centralism Against the Background of All-out Effort to Enforce Strict Party Discipline*
}

\author{
Meng Lan \\ College of Marxism \\ Northwest Polytechnic University \\ Xi'an, China 710129
}

\begin{abstract}
Democratic centralism is the fundamental organizational principle of China. As the basic system of the party and the country, it is the greatest institutional advantage of Chinese Communist party. Under the new circumstances, the key to resisting new risks and improving the party's level of governance and its ability to govern lies in inheriting and optimizing democratic centralism. Since the 18th National Party Congress, the party Central Committee with General Secretary Xi Jinping as the core has firmly grasped the institutional advantages of the democratic centralism, closely integrated ideological party building with the system of party administration, and actively explored an effective way to realize the all-out effort to enforce strict party discipline, forming a party building party to manage the party's new ideologies, new ideas, and new strategies.
\end{abstract}

Keywords-political construction; all-out effort to enforce strict party discipline; democratic centralism

\section{INTRODUCTION}

The report of the 19th Communist Party of China National Congress points out that the political construction of the Communist Party of China (CPC) is the fundamental construction that determines the direction and effectiveness of construction. China's principle is to put priority on the political construction. Such report is not only the construction of all-out effort to enforce strict party discipline since 18th Communist Party of China National Congress, but also a higher requirement to further political construction in CPC. Xi, General Secretary, stressed many times: all-out effort to enforce strict party discipline is based on education as well as institutional regulation. Both of them share the characteristics of being gentle and strict, taking effect at the same direction and at the same time. ${ }^{1}$ That is the combination of ideological party building and systematic party governance referred to as combination of "inner and

*Project: The stage achievements of the Research Project "Yan'an Spirit and all-out effort to enforce strict party discipline in New Era" (Project No.: 17HSJD-13) in the Key Base of Humanities and Social Sciences of the Ministry of Education in 2017.

Xi Jinping. Speech at the Conference of Summary Regarding the Education Practice of Party's Mass Line [N]. People's Daily: October-9, 2014. outer" based on Democratic Centralism. Ideological Party building is the essence of all-out effort to enforce strict party discipline to ensure the purity of party members' ideology; systematic party governance is the key of all-out effort to enforce strict party discipline to guarantee the standardization of party members' manners.

\section{BUILDING PARTY STRICTLY IN ACCORDANCE WITH IDEOLOGY - IDEOLOGY BASIS OF ALL-OUT EFFORT TO ENFORCE STRICT PARTY DISCIPLINE}

Ideological construction is a great creation that Marxism and Leninism combine with unique practice of China. It is the crucial guarantee and basis experience for keeping progressiveness and purity of CPC. Xi, General Secretary pointed out: only with the combination of ideology and will in the entire party can people unite the ideology and will of whole nation with different ethnic groups with the aim of forming tremendous join force that promote reform. ${ }^{2}$

\section{A. Sticking to Ideal Belief, and Comprehending the Right Direction}

$\mathrm{Xi}$, General Secretary put forward that sticking to the ideal belief and insist on pursuing spiritual pursuit of communists have always been the essence of the existence of communists. The faith in Marxism and the faith in Socialism and Communism have always been the soul of communists and the spiritual support when confronting with any challenges faced by communists. ${ }^{3}$ This serves as the major difference between Communist Party and other parties. Under the new situation and tempted by domestic and foreign sectors, most of our members persist with ideal faith, insisting on keeping China's original aspiration and stick to China's mission firmly in mind. However, very few members pursue individual interest without any sense of awe and ethic

\footnotetext{
Xi Jinping Made a Speech About Governing the Country [M] Beijing: Foreign Language Publishing House, 2014: 90.

Literature Research Room of the Central Committee of the Communist Party of China. Xi Jinping's Abstract on the Comprehensive Effort to Enforce Strict Party Discipline [M]. Central Documentation Publishing House, 2016: 57.
} 
base. This is due to a fundamental reason that their faith has shaken.

All members should be aware of forming the ideal faith as guidance in practice. That is sticking to "the faith in Marxism and the faith in Socialism and Communism". That is to learn theories thoroughly, insist on ideal faith and comprehend the right political direction. Secondly, members are expected to carry out the problem-oriented criticism and self-criticism in a right way on the basis of democratic centralism- the self-reflection among all party members who intend to correct and improve themselves. Finally leaders' especially senior officials who set an example for party members and the masses should enable them to feel powerful force of ideal faith

\section{B. Enhancing Four Awareness, Keeping up with the Core Principle}

Centralization means the centralizing the power and awareness. Enhancing "Four Awareness" especially Follow the Leadership Core, and Keep in Alignment serve as an important measure in maintaining the authority of the Party Central Committee. Friedrich Engels stressed that it is ridiculous to regard principle of authority as absolute bad thing and see the principle of autonomy as absolute good thing. ${ }^{4}$ To ensure the role of leader is not for the cult of personality. "The establishment of key leadership team in party is not simply for "centralization" or roughly "authoritarianism" rather it is the centralization under the guidance of democracy meanwhile we strive to achieve democracy by centralization. It is an innovation and development of democratic centralism.

"The awareness of keeping up with the policy" states that all party members should keep up with Central Committee of the Communist Party of China with Xi Jinping, the general secretary as the key role in leadership, ideological theory, approaches, and principles. This is the inner requirement of law regarding the construction of the ruling party. Meanwhile it is also an inner measurement of "Four Awareness". Ma Zedong stressed that "it is known that a team is not always in order." Therefore what we usually call in a team is "eyes left" "eyes right" "eyes center". Thus what required is that we must keep up with the central standard and conference standard. Keeping up with them is the principle. However the emerge of errors is practice. When errors appear, we ask everyone to keep up with Chinese principle. ${ }^{5}$ Under the new trend, increasing the awareness of keep up is the scientific acknowledge of the approach and measures in CPC. In accordance with the central leadership team led by Xi Jinping the general secretary, every party member should follow the principle of "the entire membership of the Party is subordinate to the Central Committee", unifying the awareness and realizing and maintaining the authority of Central Committee from organizational perspective.

Selected Section of Marx and Engels (Volume 3) [M]. Beijing People's Publishing House. 2012: 276.

Mao Zedong's Collection of Works (Volume 3) [M]. People's Publishing House, 1996: 297-298.
III. GOVERNING THE PARTY ON AN INSTITUTIONAL LEVEL PLAYS A KEY ROLE IN ALL-OUT EFFORT TO ENFORCE STRICT PARTY DISCIPLINE

Rules regulates action as $\mathrm{B}$. Guy Peters points out that institution regulates a set of behavioral expectation of different individual position within an institution and enhance behaviors that fits the role and punish those behaviors that don't fit its role. ${ }^{6}$ An organization must formulate relevant rules and regulations to ensure its proper function.

\section{A. Putting Priority on Key Minority and Fully Ensuring Democracy Within the Party}

$\mathrm{Xi}$, General Secretary addressed in the report of the 19th Communist Party of China National Congress that "improving and applying each policy in democratic centralism and insisting on the combination of centralization based on democracy and democracy guided by centralization fully promote democracy but for the benefit of centralization. $^{7 "}$ This statement is a conclusion of new experience in institutional construction under the background of all-out effort to enforce strict party discipline

Faced with new situation and task, Xi, General Secretary has arranged new strategies on all-out effort to enforce strict party discipline, focusing on the idea that enforcing strict party discipline is to manage leaders strictly. ${ }^{8}$ Leaders from every level are the practitioners of Socialism with Chinese Characteristics. The quality of implementation directly influences the entire leadership team, which concerns the sound development of the whole political life in the Party. Leaders who shoulder their own responsibly set a good example. That is no to say leaders are responsible for all or sanctification of leaders. Any form of personality cult at any time should be objected. To prevent and avoid key leaders who give the last word in major issue is to respect the dominant role of party members and protect their rights not to be violated. Every level of Party branch should take the initiative to listen to the advice and suggestion from subordinate before important decisions are made to improve the approach from scientific and democratic perspective. Secondly Subordinates are required to deliver report when implementing major policies to realize the interaction of information between superiors and subordinates.

Putting priority on minority is the key section that ensures democracy in the Party under the background of allout effort to enforce strict party discipline. It is also a flexible application and development of democratic centralism after the 18th Communist Party of China National Congress. The

\footnotetext{
$6 \quad$ B.Guy Peters. Institutional Theory in Political Science: "The New Institutionalism. Translated by Wang Xiangmin, Duan Hongwei. Shanghai: Shanghai People's Publishing House, 2016: 31.

Xi Jinping. Achieving victory in creating a well-off society in an all-round way and win the great victory of socialism with Chinese characteristics in the new era. Report at the 19th National Congress of the Communist Party of China [J], Party Building, 2017 (11): 32.

$8 \quad$ Writing Team. Comprehending "Key Minorities" and Deepening Comprehensive Effort to Enforce Strict Party Discipline [M], Beijing: Xinhua Publishing House, 2017: 34-36.
} 
reason of a strong and powerful Party is because of the principle: Party is in charge of managing cadres and sticking to this Principe on your own initiative. ${ }^{9}$ Every Party brand focuses on this section to regulate political life in the Party and future promotes a new development of all-out effort to enforce strict party discipline.

\section{B. Improving the Construction of Integrity in the Party and Regulating Life Within the Party}

Xi General Secretary addressed in the report of the 19th Communist Party of China National Congress that "fully promote political construction, ideological construction, organizational construction, ethnic construction, discipline construction in the Party; integrate institutional construction within the process; enhance in depth anti-corruption. ${ }^{10}$ "To improve the integrity construction of anti corruption requires the awareness that members dare not to be corrupt, can't be corrupt, unwilling to be corrupt. Meanwhile a complete and sound supporting system is in great demand to ensure the purity and progressiveness of all Party Members and enable power to serve for the people. In new situation, Central Committee has published a series of relevant regulations such as Regulations on the Inspection of the Communist Party of China, Rules for the Integrity and Self-discipline of the Communist Party of China, Regulations on Disciplinary Sanction of the Communist Party of China that promote the integrity construction of ethics in the Party. ${ }^{11}$ Rules for the Integrity and Self-discipline forms the ideology of "not willing to be corrupt". Regulations on the Inspection creates the atmosphere of "not wanting to be corrupt". Regulations on Disciplinary Sanction forms the fence of "unable to be corrupt". Regulations on Disciplinary Sanction serves as the baseline of stressing the discipline and rules, proving the guarantee for "unable to be corrupt". Regulations on the Inspection contributes to the effectiveness of "unable to be corrupt" to ensure the application of every regulation.Rules for the Integrity and Self-discipline, Regulations on Disciplinary Sanction and Regulations on the Inspection are the concrete expression of Party Constitution to promote the integrity construction of ethics in the Party and to improve the purity and progressiveness of the Party. The combination of "Construction of Institution" "Implementation" and 'Inspection" place all Party Members under the sunshine to improve the ability of anti-corruption and change prevention, improving the integrity construction of ethics in the Party and regulate political life within the Party as well as maintaining the authority of the Central Committee.

\footnotetext{
Xi Jinping Made a Speech About Governing the Country [M]. Beijing: Foreign Language Publishing House, 2017: 190.

Xi Jinping. Achieving victory in creating a well-off society in an all-round way and win the great victory of socialism with Chinese characteristics in the new era. Report at the 19th National Congress of the Communist Party of China [J], Party Building, 2017 (11): 32.

11 Ren Zhongwen (Editor). Comprehensive Effort to Enforce Strict Party Discipline is always on the way [M]. Beijing: People's Daily Press,
} 2017: 145.

\section{CONCLUSION}

Communist Party of China focused on the construction of the Party from its beginning. Since the reform and opening up, leaders throughout the history have explored and reflected on issues such as constructing what sort of Party and how to construct it under the guidance of Marxism and made great achievement. There is no present tense concerning all-out effort to enforce strict party discipline. In the new situation, all-out effort to enforce strict party discipline can only be achieved on the integration and independence of building the Party strictly and governing the Party systematically. Building the Party strictly from ideological perspective is the soul that answers what sort of the Party it is, how to quicken the pace of the great rejuvenation of the Chinese nation and put forward a higher requirement for the Party. Practices have shown that communists who obtain a firm ideal faith are able to obtain a firm political behaviors. Only with a firm action, can we carry out the construction of socialist modernization. Regulation within the party ensure the smooth implementation of building the party strictly from ideological level and answering the question of what sort of Party we should build. The key of institutional construction is the construction of democratic centralism.

Faced with difficulties, the approach of all-out effort to enforce strict party discipline should be further implemented. Since 18th Communist Party of China National Congress, the leadership team with Xi Jinping as the leading role issued military order to follow all-out effort to enforce strict party discipline. From ideological and institutional level, the Central Committee launched educational activities with the theme of ideal faith by top- down strategies on the basis of democratic centralism. While combating corruption with "Zero Tolerance" and regulating political life within the Party(imposed strict accountability to Party members who sabotaged the election by bribery in Hengyang, Henan and carried out thorough investigation to Party Members who lobbied and got elected by bribery ; gave severe punishment to all who involved in these cases), the overall quality of Party members have been generally improved to ensure the progressiveness and purity of the Party in accordance with the principle: all measures should be applied and strictly implemented. Under the new situation, it is required to promote the in-depth development of all-out effort to enforce strict party discipline.Continually insisting on all-out effort to enforce strict party discipline, carrying out educational practice in terms of the Party's Mass Line; theme education "Three Strictness, Three Practices"; learning course "Two Acknowledge, One practice"; forming "Four awareness" keep a high consistency with Central Committee ideologically. Sticking to the principle of governing the Party by institution, comprehending and implementing regulations such as Several Guideline of Political Life Under the New Situation and Regulation of the Supervision Within the Communist Party of China requires the combination and reciprocity of power and responsibility. All in all, Party Members especially leading cadres should comprehend the content and principle of democratic centralism, fully promoting strict restriction to governing the Party, gradually 
improving and perfecting the leadership. Being proficient in applying democratic centralism in maintaining the authority of the Party and country to ensure the unity of whole Party and country, to create a prosperous life for people and pave the way for a broader vision for Socialism with Chinese Characteristics.

\section{REFERENCES}

[1] Selected Section of Marx and Engels (Vol. 3) [M]. Beijing: People's Publishing House. 2012.

[2] Collected Works of Deng Xiaoping's (Vol. 2) [M]. Beijing: People's Publishing House, 2014.

[3] Collected Works of Mao Zedong (Vol. 3) [M]. Beijing: People's Publishing House, 1991.

[4] Lenin Mao Zedong and Deng Xiaoping on Democratic Centralism [M]. Founder Press of China, 1994.

[5] Xi Jinping Made a Speech About Governing the Country (Vol. 2) [M]. Beijing: Foreign Language Publishing House, 2017.

[6] Xi Jinping Made a Speech About Governing the Country [M]. Beijing: Foreign Language Publishing House, 2017. 